\title{
Effect of Selenium-Enriched Garlic Oil against Cytotoxicity Induced by OX-LDL in Endothelial Cells
}

\author{
Cheng Yang, ${ }^{1}$ Kai Cui, ${ }^{2}$ Yutao Diao, ${ }^{3}$ Min Du, ${ }^{1}$ and Shumei Wang1 \\ ${ }^{1}$ School of Public Health, Shandong University, NO. 44 West Wenhua Road, Jinan 250001, China \\ ${ }^{2}$ School of Public Health Administration, Liaoning Medical University, Jinzhou 121000, China \\ ${ }^{3}$ Shandong Academy of Medical Sciences, Jinan 250012, China \\ Correspondence should be addressed to Cheng Yang; ppang0314@gmail.com and Shumei Wang; 429128236@qq.com
}

Received 29 March 2014; Accepted 15 May 2014; Published 29 May 2014

Academic Editor: Waris Qidwai

Copyright (C) 2014 Cheng Yang et al. This is an open access article distributed under the Creative Commons Attribution License, which permits unrestricted use, distribution, and reproduction in any medium, provided the original work is properly cited.

\begin{abstract}
Objective. To detect the effect of selenium-enriched garlic oil (Se-garlic oil) against cytotoxicity induced by ox-LDL in endothelial cells. Methods. Se-garlic oil was extracted by organic solvent extraction. High performance liquid chromatography (HPLC) was used to detect the content of allicin in the Se-garlic oil. Hydride generation atomic fluorescence spectrometry (HG-AFS) was used to detect the content of Se in the Se-garlic oil. ECV-304 cells were separated into five groups (blank, ox-LDL, and low-, medium-, and high-dose Se-garlic oil). Methyl thiazolyl tetrazolium (MTT) assay was used to detect the cytoactivity of each cell group after culturing for 24, 48, and 72 hours. Flow cytometry (FCM) stained with annexin V-FITC/PI was used to detect the apoptosis of the cells from the blank, Se-garlic oil, ox-LDL, and Se-garlic oil + ox-ldl groups after 48 hours of incubation. Results. The amount of allicin in Se-garlic oil was $142.66 \mathrm{mg} / \mathrm{ml}$, while, in Se, it was $198 \mathrm{mg} / \mathrm{kg}$. When ox-LDL was added to low-, medium-, and highdose Se-garlic oil, the cell viability rates of ECV-304 cells treated in the three groups were all higher, while the apoptosis rates were significantly lower than those of the ox-LDL group $(P<0.05)$. However, there was no significant difference between the apoptosis rates of the blank, Se-garlic oil, and Se-garlic oil + ox-LDL groups $(P>0.05)$. Conclusion. Se-garlic oil could inhibit the cytotoxic effect induced by ox-LDL in endothelial cells.
\end{abstract}

\section{Introduction}

Oxidized low-density lipoprotein (ox-LDL) can cause injury and disability to vascular endothelial cells. This is considered to be related to the beginning of atherosclerosis (AS) formation $[1,2]$.

Research has found that garlic and its related products could counteract risk factors which would lead to AS [3]. Garlic not only could lower blood lipid level but also has an anticoagulant effect. Furthermore, garlic has an antioxidant effect in which it can cut off the oxidation of LDL, so it can prevent the formation and toxic effect of ox-LDL [3-6].

Selenium (Se) is one of the essential microelements, and it can lower endothelial cells' apoptosis and expression of adhesion molecules, which are caused by oxidative stress, high-fat diet, and other factors. Se is also known to be an anticoagulant and antioxidant [7-11].
Efforts have been made to combine garlic with Se to enhance the ability to counteract AS. Our research group, in a previous animal assay, found that allicin combined with Se can lower the blood lipid level of rabbits induced by a highfat diet [12]. However, we found that garlic is opposite to Se in $\mathrm{pH}$ value in vitro, so their bioactivity is lowered, when they are simply mixed. Se-garlic is cultivated in selenium soil. Garlic can absorb inorganic Se, then changing it into organic Se by biological accumulation and biological transformation. In this way compared to inorganic Se, the hepatotoxicity and nephrotoxicity are less, and a moderate price and convenience can be attained.

Animal studies have found that Se-garlic has higher bioactivity than garlic or Se alone, and it is not significantly accumulated in the liver and kidneys $[13,14]$.

There has been little research on Se-garlic's effect against AS. The purpose of the present study was to find whether 
Se-garlic oil can act against the cytotoxicity induced by oxLDL in endothelial cells.

\section{Materials and Methods}

\subsection{Experimental Method}

2.1.1. Preparation of Garlic Oil and Determination of Allicin and Selenium Content in the Oil. We extracted the garlic oil from the Se-enriched garlic (Shandong Xingfa Agricultural Science and Technology Co. LTD.) by an organic solvent extraction process. High performance liquid chromatography (HPLC) was used to detect the amount of allicin in the Se-garlic oil. Hydride generation atomic fluorescence spectrometry was used to detect the content of Se in the Segarlic oil.

2.1.2. Cell Culture and Treatment. The human umbilical vein endothelial cell line EVC-304 was cultured in RPMI1640 medium (Gibco, Los Angeles, USA) supplemented with $10 \%$ heat inactivated FBS, $100 \mu \mathrm{g} / \mathrm{mL}$ penicillin, $100 \mu \mathrm{g} / \mathrm{mL}$ streptomycin, and $2 \mathrm{mM}$ L-glutamine and maintained in a humidified atmosphere with $5 \% \mathrm{CO}_{2}$ at $37^{\circ} \mathrm{C}$. The cells were subcultured twice each week and the exponentially growing cells were used in all treatments. Before treatment, cells were washed with PBS and fresh medium was added. At the time of treatment, working solutions were diluted accordingly in RPMI1640. The drugs were added to the cells $12 \mathrm{~h}$ after the subculture.

2.1.3. Cell Viability Rate Assay. Cell viability rate was assessed by methyl thiazolyl tetrazolium (MTT) assay (Mosmann, 1983). The assay calculated the inhibition rate of cell viability treated by the drug. The design assay of the Se-garlic oil impact on the cell viability of EVC-304 cells included blank and seven-dose groups of the Se-garlic oil $(5,10,20,40,80$, 160 , and $320 \mu \mathrm{L} / \mathrm{mL}$ ) and, for ox-LDL-induced cytotoxicity on EVC-304, four doses of concentrations of ox-LDL (10, 20, 40 , and $80 \mu \mathrm{g} / \mathrm{mL}$ ) (Beijing Xiesheng NZCB). Each was done three times.

In the MTT assay, the untreated cells were generally in the exponential growth phase, and single-cell suspensions of $1 \times$ $10^{5} \mathrm{cell} / \mathrm{mL}$ were inoculated into three 96 -well plates, $200 \mathrm{uL}$ per well. Cell groups were exposed to different concentrations of the drug for various time periods. Three plates were made and were cultivated for 24,48 , and 72 hours.

$20 \mathrm{uL}$ of MTT solution was added to each well 4 hours before the end and then centrifuged and the supernate was discarded. $150 \mathrm{uL}$ of dimethyl sulfoxide (DMSO) solution was added into each well. Absorbance values $(A)$ were detected by a microplate reader (mode FL 330, BioTek Instruments, Winooski, VT) at dual wavelength of $570 / 630 \mathrm{~mm}$ after shaking slightly for 10 minutes. The number of cells was also established using a hemocytometer, and all the results represented the average. The above experimental procedures were repeated three times. The viability rate of cells was calculated by using the following formula: viability of cell $(\%)=$ (the average value of the experimental group/the average value of the control group) $\times 100 \%$.

2.1.4. Testing the Se-Garlic Oil's Effect against the Cytotoxicity Induced by Ox-LDL in EVC-304 Cells. Based on $50 \%$ effective concentration of inhibition in the above assay, $40 \mu \mathrm{g} / \mathrm{mL}$ ox-ldl was selected as the inducing cytotoxicity concentration in the test. The design assay of Se-garlic oil against the cytotoxicity induced by ox-LDL in the EVC-304 cells included five groups: blank, ox-LDL, and ox-LDL+ three dose concentrations of the Se-garlic oil $(15,30$, and $60 \mu \mathrm{L} / \mathrm{mL})$. The MTT test was used to detect the cell activity rate. The experimental procedures were repeated three times.

2.1.5. Cell Apoptosis Assay. The Se-enriched garlic oil's effects against apoptosis induced by ox-LDL were tested using a flow cytometer. The design assay included four groups: blank, ox-LDL $(40 \mu \mathrm{g} / \mathrm{mL})$, Se-garlic oil $(30 \mu \mathrm{L} / \mathrm{mL})$, and ox-LDL $(40 \mu \mathrm{g} / \mathrm{mL})+$ Se-garlic oil $(30 \mu \mathrm{L} / \mathrm{mL})$.

Forty-eight hours after culture, cells were trypsinized; $1 \times 10^{6}$ cells per sample were washed twice with ice-cold PBS solution, and then $5 \mu \mathrm{L}$ of annexin V-FITC (AV) and $10 \mu \mathrm{L}$ of propidium iodide (PI) (Sigma Chemical Company, St. Louis, USA) were added to $100 \mu \mathrm{L}$ of cell suspension, followed by incubation for $15 \mathrm{~min}$ at room temperature in the dark. Finally, $400 \mu \mathrm{L}$ of binding buffer was added to each sample, and then the mixture was filtered by a 300-mesh nylon net before EPICS XL (Beckman Coulter, Bren, CA, USA) flow cytometry. EXPO32 ADC analysis software was used to analyze the data.

2.2. Statistical Analysis. SAS 9.1 was used for statistical analysis. Single factor analysis of variances was used for comparison among groups. The least-significant difference (LSD) test was performed for comparison between two groups. Multiway ANOVA was used for interaction. There was statistical significance if $P$ value was below 0.05 .

\section{Result}

3.1. Determination of Allicin and Selenium Content. As shown in Figure 1, allicin's retention time was 9.339 min. A linear regression model was adapted to fit the data. The peak area was set as the dependent variable, and the content of allicin was set as the independent variable. The regression equation was $Y=13.086 X+509.977\left(R^{2}=0.998, P<0.01\right)$. The content of allicin in the Se-enriched garlic oil was calculated as $142.66 \mathrm{mg} / \mathrm{mL}$, and the content of Se detected by hydride generation atomic fluorescence spectrometry was calculated as $198 \mathrm{mg} / \mathrm{kg}$.

3.2. Cell Viability Rate Assay. As shown in Figure 2, EVC-304 cells were treated with $0,5,10,20,40,80$, and $160 \mu \mathrm{L} / \mathrm{mL}$ of Segarlic oil using the MTT method. The cell proliferation rates showed time and dose dependence.

Based on EC4-304 cell's survival rate concentration-effect curve induced by the Se-garlic oil, we chose $30 \mu \mathrm{L} / \mathrm{L}$ to be the middle concentration group to counteract ox-LDL in later 


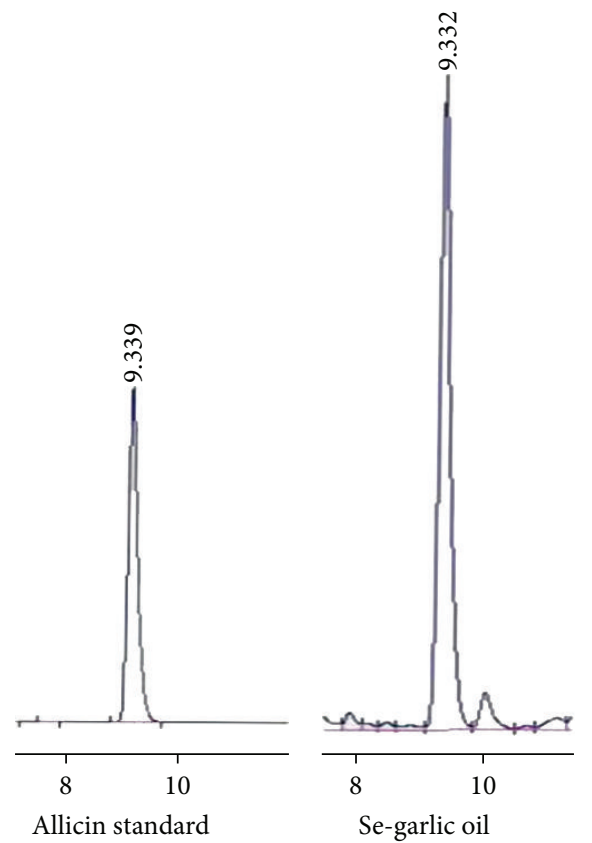

FIGURE 1: Content of allicin in raw Se-enriched garlic.

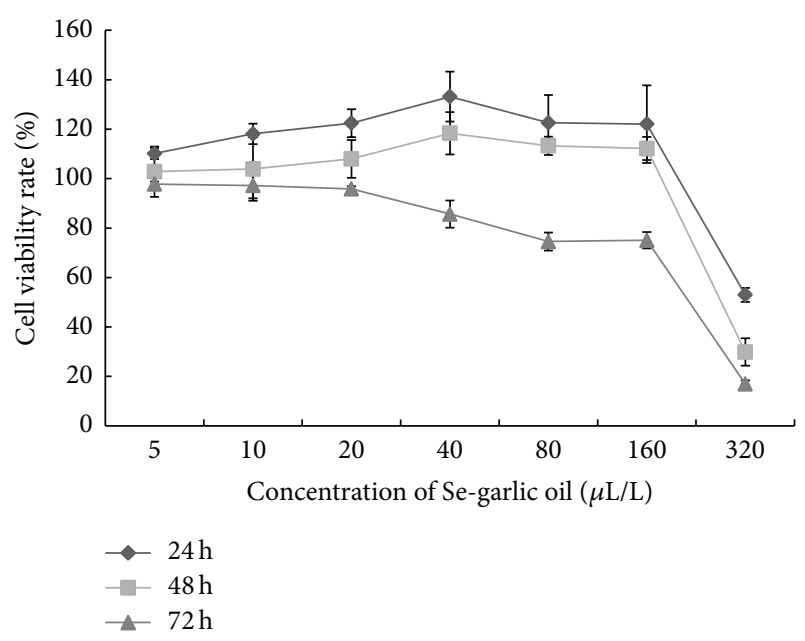

FIGURE 2: Curve of ECV-304 cell activity rate.

experiments. We then respectively chose half time and 2 times $(15 \mathrm{uL} / \mathrm{L}, 60 \mathrm{uL} / \mathrm{L})$ as the low and high concentration groups.

As shown in Figure 3. In order to find the effect of Segarlic on cell injuries induced by ox-LDL, we chose the ox-LDL concentration which could inhibit cell activity in all three time groups with a cell activity rate near 50\% (40 ug/mL) for the later experiment.

3.3. Se-Garlic Oil's Effect against Cytotoxicity Induced by $O x$ $L D L$ in EVC-304 Cells. As shown in Figure 4, as results of one-way analysis of variance, the cell activity rates of low, medium, and high consistency groups were all higher than the ox-LDL group after 24,48 , or 72 hours $(P<$ $0.05)$. When the interaction of time and concentration was

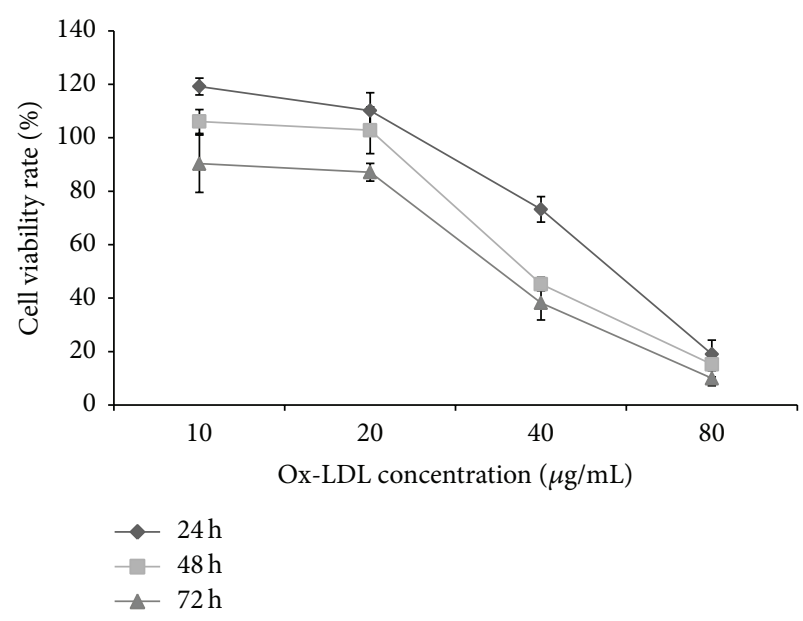

Figure 3: Curve of ECV-304 cell activity rate.

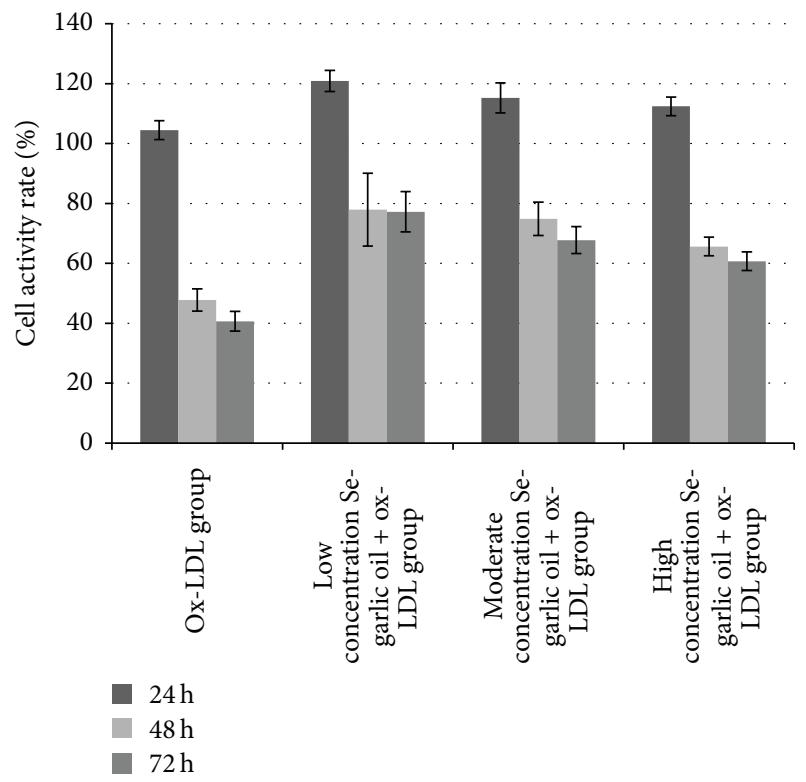

FIGURE 4: Effect of the Se-garlic oil on ECV-304 cell activity rate.

eliminated by multivariate analysis of variance, there was no statistically significant difference among low, medium, and high consistency groups after 24 hours $(P=0.29)$. The cell activity rate of the high consistency group was lower than that of the low and medium consistency groups after 48 hours $(P=0.01)$, and there was no statistically significant difference between the low group and medium consistency group $(P>0.05)$. There was a statistically significant difference only between the low and high consistency groups after 72 hours $(P=0.02)$. At the same concentration, there was no statistically significant difference between cell activity rates after 48 and 72 hours $(P>0.05)$, both of which were lower than cell activity rates after 24 hours $(P<0.05)$.

3.4. Cell Apoptosis Assay. Results of the flow cytometry capacity model (FCM) are listed in Figures 5 and 6. The 

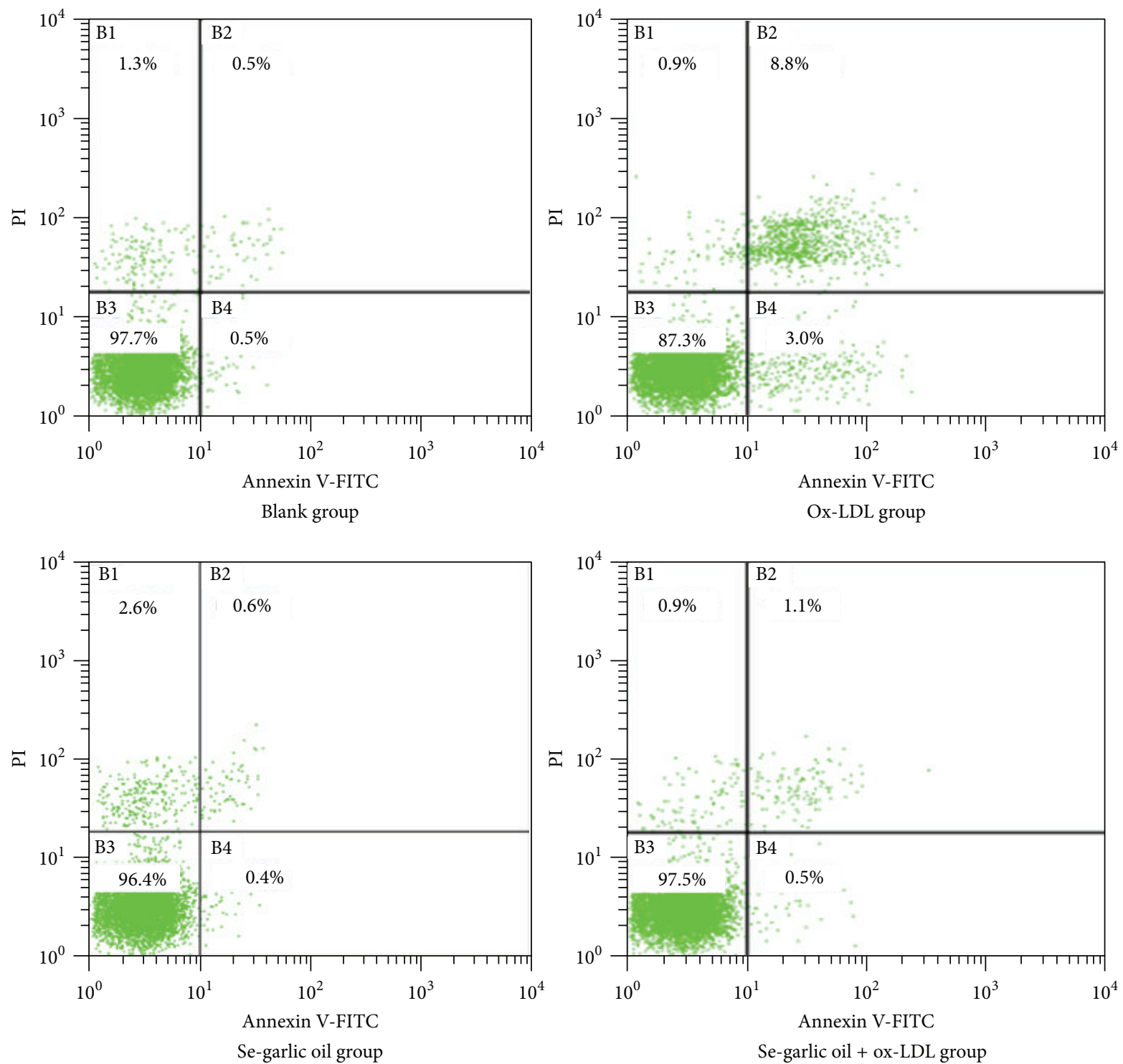

FIGURE 5: Apoptosis rate in different groups.

apoptosis rate of the ox-LDL group was significantly higher than the others $(P<0.05)$, and there was no statistically significant difference among the other groups $(P>0.05)$.

\section{Discussion}

Endothelial cells' survival rate decrease and apoptosis increase are the two main features of endothelium injuries. Garlic oil (the main component of Se-garlic) was extracted to study Se-garlic's effect on endothelium protection from these two aspects. Tests found that either allicin or selenium in Segarlic is significantly higher than that of traditional garlic [15$18]$.

The cell activity rate curve affected by the Se-garlic oil showed that the cell activity rate decreased as the concentration of Se-garlic oil increased over time and that the cell activity rate first increased and then decreased after 24 and 48 hours. This trend suggested that both garlic and Se can stimulate cell activity rate at a low concentration or in a short time, but they will inhibit cell activity rate at a high concentration $[19,20]$.

According to the ox-LDL-induced curve, when the concentration of ox-LDL was at 10 or $20 \mu \mathrm{g} / \mathrm{mL}$ or the time was 24 or $48 \mathrm{~h}$, the cell activity rate approached $100 \%$, while when the concentration was $40 \mu \mathrm{g} / \mathrm{mL}$, cell activity rate approached $70 \%$ after $24 \mathrm{~h}$ and $50 \%$ after 48 and $72 \mathrm{~h}$. However, when the concentration was $80 \mu \mathrm{g} / \mathrm{mL}$, it had a significant effect on the cell activity rate, and the cell activity rate was below $20 \%$. As a result, ox-LDL could stimulate cell activity rate at a low concentration or in a short time, but it could inhibit cell activity rate at a high concentration [21-23].

As the results showed, endothelial cells' activity was inhibited by ox-LDL, while the Se-garlic oil could oppose the inhibition effect. This suggested that Se-garlic could 


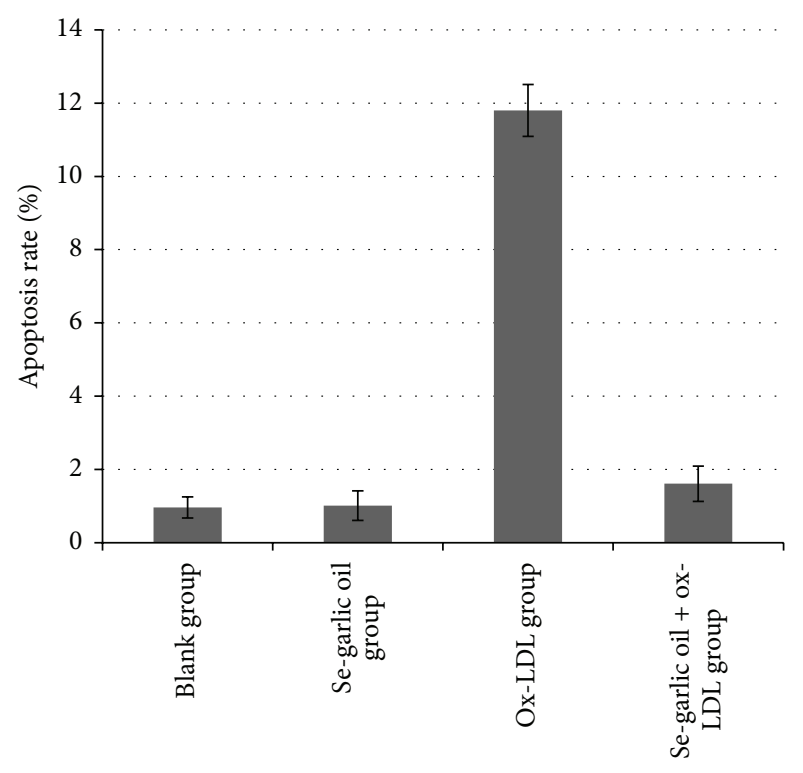

Apoptosis rate (\%)

FIGURE 6: Comparison of apoptosis rate in different groups.

counteract AS to a certain extent. The survey also found that the cell viability rate of each group decreased with time and this may be because ox-LDL's inhibition of endothelial cells activity was time dependent. The cell activity rate of each group first increased and then decreased, although there were not any significantly statistical differences. The reason for this needs further study, but one possible reason is that the environment for the growth of cells was changed by the mixture of the Se-garlic oil and ox-LDL. As a result of limited time and budget, we only studied Se-garlic's effect on endothelial cells' apoptosis which was stimulated by ox-LDL that was observed at a single concentration and time, but Segarlic could effectively inhibit the effect of ox-LDL, which suggested that Se-garlic could inhibit AS.

To sum up, according to the preliminary experiments, the Se-garlic oil could inhibit ox-LDL's toxic effect on endothelial cells, and it overcomes the defect of simply mixing inorganic Se with garlic oil which will lower their bioactivity. Further studies are needed to probe into the mechanism and whether an addictive effect or synergistic effect of allicin and Se exists in Se-garlic.

\section{Conclusion}

Endothelial cells' activity was inhibited by ox-LDL, while the Se-garlic oil could oppose the inhibition effect. This suggested that Se-garlic could counteract AS to a certain extent.

\section{Conflict of Interests}

The authors confirm that there is no actual or potential conflict of interests in relation to this paper. I would like to declare on behalf of all the other coauthors that the work described was original research that has not been published previously and is not under consideration for publication elsewhere, in whole or in part. All the authors listed have approved the paper that is enclosed.

\section{Acknowledgment}

Thanks are due to Dr. Edward C. Mignot, Shandong University, for linguistic advice.

\section{References}

[1] J. Galle, T. Hansen-Hagge, C. Wanner, and S. Seibold, "Impact of oxidized low density lipoprotein on vascular cells," Atherosclerosis, vol. 185, no. 2, pp. 219-226, 2006.

[2] C. Napoli, "Oxidation of LDL, atherogenesis, and apoptosis," Annals of the New York Academy of Sciences, vol. 1010, pp. 698709, 2003.

[3] C. Borek, "Antioxidant health effects of aged garlic extract," Journal of Nutrition, vol. 131, no. 3, pp. 1010S-1015S, 2001.

[4] K. Rahman, "Effects of garlic on platelet biochemistry and physiology," Molecular Nutrition and Food Research, vol. 51, no. 11, pp. 1335-1344, 2007.

[5] B. H. S. Lau, "Suppression of LDL oxidation by garlic compounds is a possible mechanism of cardiovascular health benefit," Journal of Nutrition, vol. 136, no. 3, pp. 765S-768S, 2006.

[6] N. Ide and B. H. S. Lau, "Garlic compounds minimize intracellular oxidative stress and inhibit nuclear factor- $\kappa \mathrm{B}$ activation," Journal of Nutrition, vol. 131, no. 3, pp. 1020S-1026S, 2001.

[7] F. Zhang, W. Yu, J. L. Hargrove et al., "Inhibition of TNF$\alpha$ induced ICAM-1, VCAM-1 and E-selectin expression by selenium," Atherosclerosis, vol. 161, no. 2, pp. 381-386, 2002.

[8] Y. Li, H. Deng, and D. Zheng, "Effect of selenium on monocyte chemoattractant protein-1 in human umbilical vein endothelial cells," Chinese Journal of Endemiology, vol. 22, no. 3, pp. 31-32, 2003.

[9] H.-T. Zheng, L.-N. Zhou, C.-J. Huang et al., "Selenium inhibits high glucose- and high insulin-induced adhesion molecule expression in vascular endothelial cells," Archives of Medical Research, vol. 39, no. 4, pp. 373-379, 2008.

[10] L. M. Sordillo, K. L. Streicher, I. K. Mullarky, J. C. Gandy, W. Trigona, and C. M. Corl, "Selenium inhibits 15hydroperoxyoctadecadienoic acid-induced intracellular adhesion molecule expression in aortic endothelial cells," Free Radical Biology and Medicine, vol. 44, no. 1, pp. 34-43, 2008.

[11] L. Li, G. Ding, and Y. Cheng, "Effect of selenium on expression of intercellular adhesion molecule-1 in rat vascular smooth muscle cells," Acta Universitatis Medicine Nanjing, vol. 23, no. 3, pp. 252-254, 2003.

[12] K. Li, S. Jing, and Y. Zhang, "Experimental research on garlic oil and selenium compound against atherosclerosis," Chinese Journal of Integrative Medicine, pp. 39-40, 1996.

[13] Y. Li, P. Wang, and Z. Li, "Se-garlic oil's interfering effects to mice with diabetes," Joural of Liangniang University of TCM, vol. 10, no. 12, pp. 160-161, 2008.

[14] W. Yang, J. Chen, W. Li, and X. Chen, "Preventive effects of 4 Se-enriched plants on rat stomach cancer induced by MNNG3. Se accumulation and distribution in rats of different selenium resources for prevention of stomach cancer," Journal of Hygiene Research, vol. 37, no. 4, pp. 435-437, 2008. 
[15] J. Ha, H. Sun, W. Tang et al., "Determination of selenium in the garlic by hydride generation atomic fluorescence spectrometry," Food Science, vol. 28, no. 2, pp. 247-249, 2007.

[16] J. Diao, L. Li, S. Yang et al., "Determination of selenium in garlic and its products using hydride generation atomic fluorescence spectrometry," Food Science, no. 4, pp. 166-168, 2009.

[17] G. Yu, Y. Wen, L. Zhang et al., "Analysis of selenium contents in vegetable in Guangzhou city," Journal of Agro-Environment Science, vol. 26, no. 3, pp. 1045-11048, 2007.

[18] X. Zhao, X. Zhao, and C. Zhao, "Determination of selenium in cangshan garlic by fluorescence spectrophotometer," Food and Drug, vol. 26, no. 3, pp. 1045-1048, 1999.

[19] F. Meng, "Protective effect of garlicin on endothelial cell injury in human umbilical vein induced by homocysteine," Chinese Journal of the Pratical Chinese With Modern Medicine, vol. 19, no. 20, pp. 2838-2840, 2006.

[20] X. Hou, X. Lin, J. Bian et al., "Effects of selenium on endothelial cell growth cultured in vitro," Journal of Environment and Health, vol. 25, no. 2, pp. 135-137, 2008.

[21] Y. Qin, J. Yang, L. Zhu et al., "Proliferation and apoptosis of human umbilical vein endothelial cells induced by oxidized low density lipoprotein," Chinese Journal of Pathophysiology, vol. 19, no. 3, pp. 334-339, 2003.

[22] A. Heinloth, K. Heermeier, U. Raff, C. Wanner, and J. Galle, "Stimulation of NADPH oxidase by oxidized low-density lipoprotein induces proliferation of human vascular endothelial cells," Journal of the American Society of Nephrology, vol. 11, no. 10, pp. 1819-1825, 2000.

[23] S. Seibold, D. Schürle, A. Heinloth, G. Wolf, M. Wagner, and J. Galle, "Oxidized LDL induces proliferation and hypertrophy in human umbilical vein endothelial cells via regulation of p27Kip1 expression: role of RhoA," Journal of the American Society of Nephrology, vol. 15, no. 12, pp. 3026-3034, 2004. 


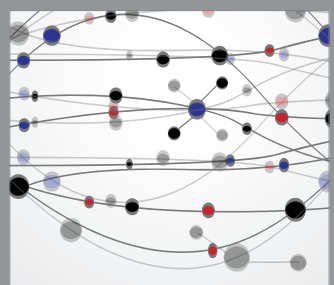

The Scientific World Journal
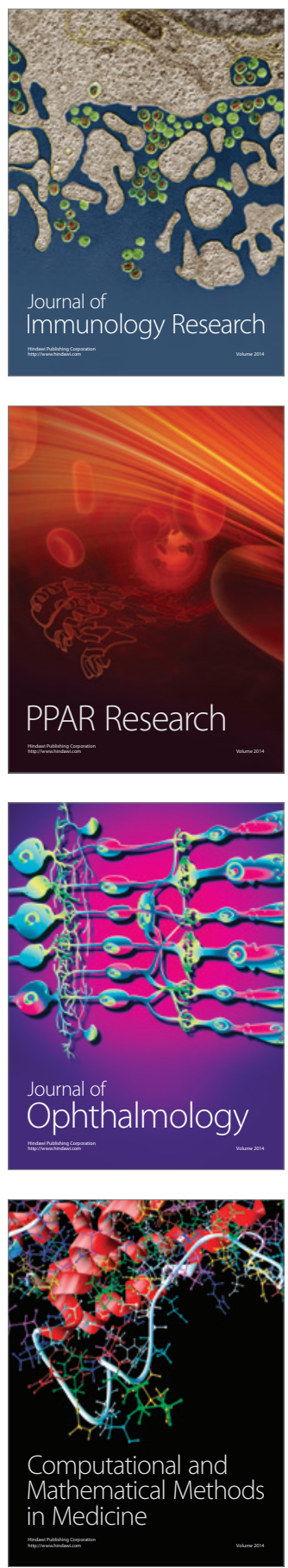

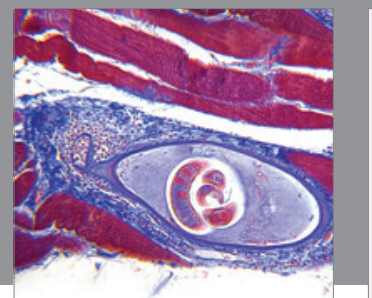

Gastroenterology

Research and Practice
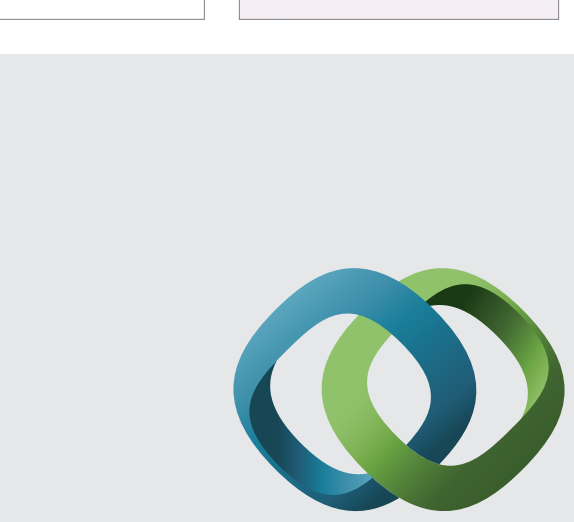

\section{Hindawi}

Submit your manuscripts at

http://www.hindawi.com
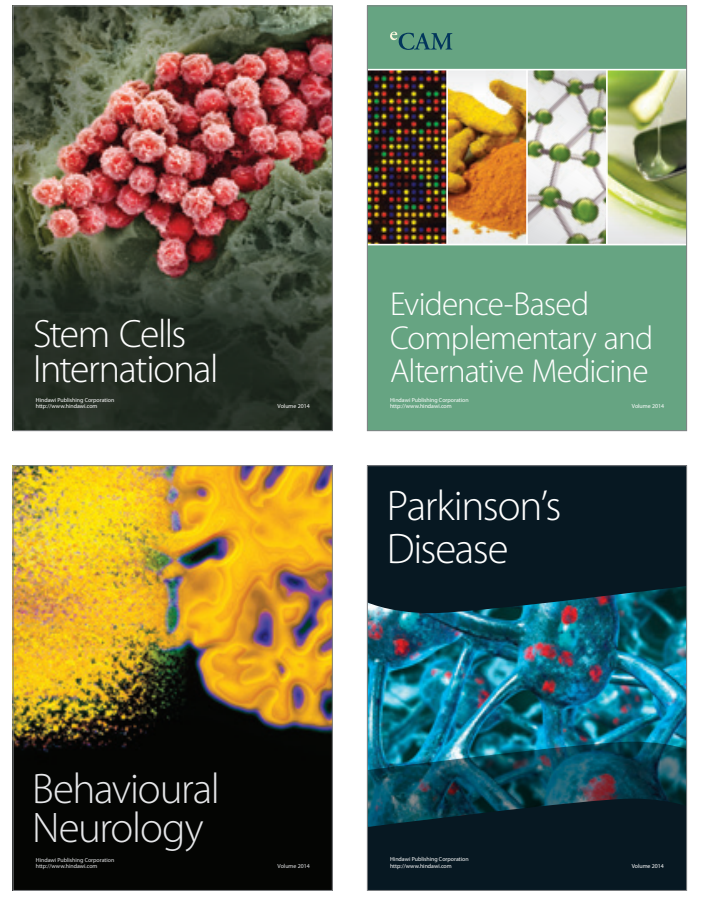
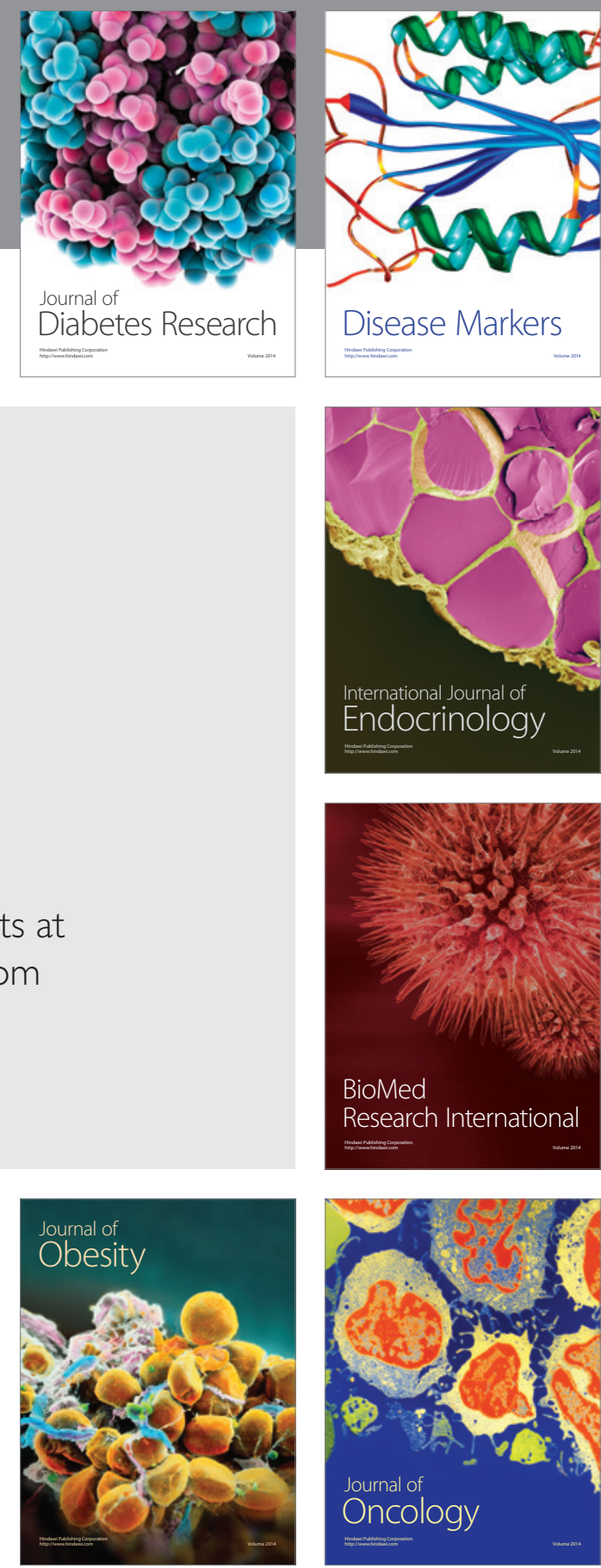

Disease Markers
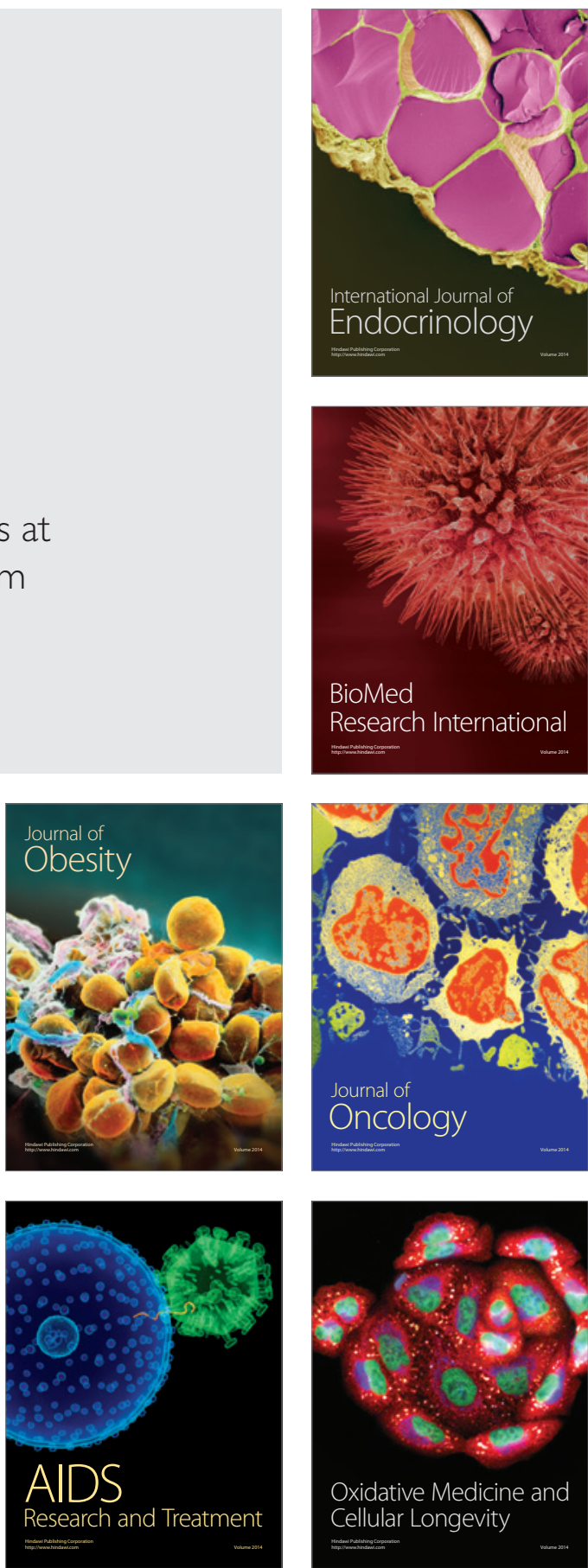